\title{
The Influence of Braiding Angle Variation in Braided-Twisted Fiber Scaffold Based Poly L-Lactic Acid for Anterior Cruciate Ligament Reconstruction Application
}

\author{
Z. Mardina ${ }^{1, a}$, N. Fitriana ${ }^{1}$, R. Siswanto $^{1}$, O. Oktavina $^{1}$, N. Zahra ${ }^{1}$, \\ P. Widiyanti ${ }^{1,2, b}$, D. Rudyarjo ${ }^{3}$, E. Indarto ${ }^{4}$, R. Langenati ${ }^{4}$ \\ ${ }^{1}$ Biomedical Engineering, Faculty of Science and Technology, Universitas Airlangga, Surabaya, \\ Indonesia \\ ${ }^{2}$ Institute of Tropical Disease, Universitas Airlangga, Surabaya, Indonesia \\ ${ }^{3}$ Physics Department, Faculty of Science and Technology, Universitas Airlangga, Surabaya, \\ Indonesia \\ ${ }^{4}$ National Nuclear Technology Agency, Serpong, Indonesia \\ amardinazahrina@yahoo.com, bdrwidiyanti@yahoo.com
}

Keywords: PLLA; Electrospinning; ACL; Scaffold.

\begin{abstract}
Anterior Cruciatum Ligament (ACL) injury may cause other tissue injuries and degenerative joint diseases, rendering major surgery compulsory. The ACL substitutions from patient's other tissue (autograft), from cadaver (allograft), or from other species (xenograft) still cause problems like donor morbidity, reduction of mechanical strength in cryopreservation period, and the risk of transgenic infection. Tissue engineering approach is the proposed solution. For this, synthetic ligament scaffold is needed. Electrospinning is a method to produce porous scaffolds made of polymers. In this study, filaments were produced from electrospinning poly l-lactic acid. The filaments were then twisted with $60^{\circ}$ angle to the horizontal to make a yarn. Subsequently, the yarns were braided with the variation of braiding angle $40^{\circ}, 60^{\circ}$ and $80^{\circ}$. The characterization on the scaffold includes degradation rate, porosity, tensile strength, and cytotoxicity. It was found that larger braiding angle gave higher degradation rate, bigger pore size, and lower mechanical strength. For cytotoxicity, in terms of pore size and percentage of living cell, scaffold with braiding angle of $80^{\circ}$ also showed the optimum result.
\end{abstract}

\section{Introduction}

The Anterior Cruciate Ligament (ACL) is a tissue in knee joint which connects tibia (lower leg) to the femur (thigh). In America, more than 250.000 patients are diagnosed to suffer from ACL torn every year and around 150.000 ACL surgeries are conducted every year. ACL torn is a significant joint injury. It causes other tissue injuries and degenerative joint diseases. The low capacity of ACL torn healing caused orthopedic chooses surgery total reconstruction to the patients. In the clinical practice, there are several options, including autograft, allograft, and xenograft. Autograft is a ligament substitute from the other tissues of the patients. It can be taken from patellar, quadriceps, and hamstring. However, those options have disadvantages. Autograft caused morbidity of tissue to the patients. Allograft has the risk in the reduction of mechanical strength in the cryopreservation period. Xenograft has the risk of transgenic infections. Based on the problems mentioned, the development of synthetic ligaments has become a necessity.

Based on previous report, synthetic ligament from Poly Lactid Glicolic Acid (PLGA) was common [1]. PLGA sustained faster degradation than PLLA. It also sustained reduction of mechanical strength. The synthetic ligaments based on PTFE and Dacron sustained slower degradation time but it caused inflammation and foreign body reaction [1].

Freeman et al. (2006) conducted a research about in vivo test of the substitute ligament [2]. The materials were used were knitted PLLA, braided collagen and also braided PLLA. As the result, it was concluded that PLLA braided degradation time is the longest. It was around 48 weeks and the other materials degraded around 4 weeks-20 weeks. Freeman also conducted a research about the number of braid (yarn) for a scaffold. It was known that the number of braids that gave maximal 
mechanical strength were around 2-4 braids. Synthetic ACL with two braids had ultimate tensile strength of $71 \pm 7 \mathrm{MPa}$, synthetic ACL with 4 braids had ultimate tensile strength of $82 \pm 2 \mathrm{MPa}$, while synthetic ACL with 6 braids had the lowest ultimate tensile strength of $44 \pm 4 \mathrm{MPa}$ [2].

In this research, single braid was used because the objective in this study was to find out the influence of braiding angle variation to the tensile strength, not about the influence from the number of braids to the tensile strength. The second objective was to find out the influence of braiding angle to the size of pores because scaffold had the porosity requirements to enable bone and soft tissue growth. The third objective was to find the influence of braiding angle to the degradation rate of scaffold and the fourth objective was to prove that the material is nontoxic.

\section{Materials and Method}

Materials. Poly L-lactid acid (PLLA) with Mw=180.000 (Polyscitech) was used. Chloroform and toluene were of reagent grade (Merck). The equipments were electrospinning unit, stationary gap collector, magnetic stirrer, optical microscope, cytotoxicity kit, and simulated body fluid (SBF) kit.

Fabrication of Scaffolds. There were three processes to create the braided-twisted fiber scaffold. The first process was to create a homogenous solution. PLLA was dissolved in chloroform and toluene with concentration of 7\% wt solute/wt solvents. The comparison of chloroform and toluene were $3: 1$. The solution was stirred at $100-500 \mathrm{rpm}$. The viscosity of the solution after stirred for 48 hours was $100 \mathrm{dPa}$. After that, the solution was stored in the refrigerator for 24 hours. The second process was to create fibers by electrospinning. The setting was voltage of $9 \mathrm{kV}$, flow rate of 36 $\mathrm{mL} /$ hour, distance between spinneret and collector was $4 \mathrm{~cm}$. Stationary gap collector was used with two parallel copper wires. One lap of electrospinning running was for $2 \times 24$ hours. After $2 \times 24$ hours, filaments of fibers were removed from between two parallel copper wires. Then it was cut into $2 \mathrm{~cm}$ $\mathrm{x} 4 \mathrm{~cm}$ for one filament (Fig. 1) and rolled to make it into rolled filament (Fig. 2). The third process was to twist and braid the filaments (Fig. 3). The twist process used $60^{\circ}$ angles and was performed manually with some patterns. Twisting angle was counted based on horizontal axis. Three filaments were twisted each others to make one yarn. Then it was made 9 yarns. Then 3 yarns were braided each other to make a scaffold. First 3 yarns were braided with $40^{\circ}$ angle, second 3 yarns were braided with $60^{\circ}$ angle, and third 3 yarns were braided with $80^{\circ}$ angle.

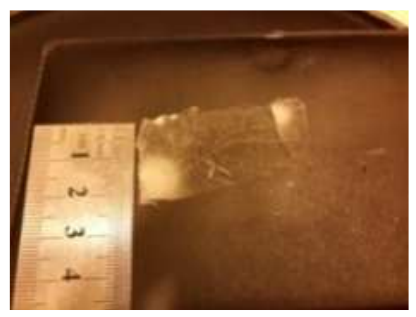

Fig. 1. Sheet filament

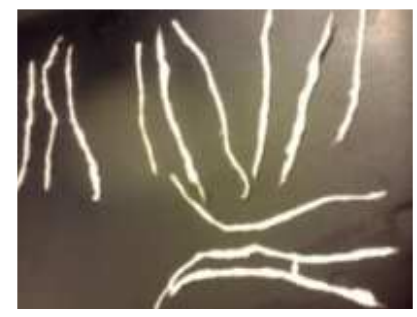

Fig. 2. Rolled filaments

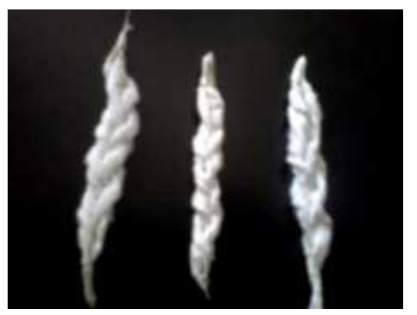

Fig. 3. Single braided-twisted fibers

Characterization. First characterization was degradation test in simulated body fluid (SBF). The $\mathrm{pH}$ was used 7.4. The test was done for 67 hours. Second characterization was microstructure test used optical microscope. Third characterization was tensile test. The fourth characterization was cytotoxicity test using MTT- assay method. There were two equations that were used for analyze the result of characterization. In simulated body fluid test, the equation used was

Degradation velocity $(\mathrm{mpy})=534 \mathrm{~W} / \mathrm{D}$. A. T

with $\mathrm{W}$ is weight loss $(\mathrm{mg}), \mathrm{D}$ is density $\left(\mathrm{g} / \mathrm{cm}^{3}\right), \mathrm{A}$ is exposed extent $\left(\mathrm{cm}^{2}\right)$, and $\mathrm{T} \quad$ is exposure time (hours).

For MTT- assay test, the equation used was

Percentage of livingcell $=\frac{O D \text { sample }+ \text { OD MediaControl }}{O D \text { Cell }+ \text { OD Media Control }}$ 


\section{Results and Discussion}

The result of degradation test is shown in Table 1 . The degradation was $2 \%$ for $40^{\circ}$ sample, $3.6 \%$ for $60^{\circ}$ sample, and $14.8 \%$ for $80^{\circ}$ sample. Then it was counted time for the scaffold to discharge completely. For sample with $40^{\circ}$ angle, the initial weight was 0.123 gram. The weight loss was $6.4 \mathrm{mg}$ every 67 hours. It can be concluded that the scaffold will be completely discharged for 1287 hours or around 53 days. Based on the previous study that was conducted by Gulotta and Rodeo (2007), it was mentioned that perfect regeneration of bone and soft tissue were around 8-12 weeks. The braided-twisted fiber scaffold in this research was suitable with the minimum standard. For reducing the degradation velocity, it can be done by adding more braids in the scaffold [3].

Table 1. Degradation test in Simulated Body Fluid

\begin{tabular}{ccccc}
\hline Braiding angle & $\begin{array}{c}\text { Exposed extent } \\
{\left[\text { in }^{2}\right]}\end{array}$ & $\begin{array}{c}\text { Eksposure time } \\
{[\text { hours }]}\end{array}$ & $\begin{array}{c}\text { Weight loss } \\
{[\mathrm{mg}]}\end{array}$ & $\begin{array}{c}\text { Degradation } \\
\text { velocity [mpy] }\end{array}$ \\
\hline $40^{\circ}$ & 0.0452 & 67 & 6.4 & 0.903 \\
$60^{\circ}$ & 0.0804 & 67 & 11.4 & 0.905 \\
$80^{\circ}$ & 0.1256 & 67 & 18.3 & 0.930 \\
\hline
\end{tabular}

Range of pore sizes was measured by pore counting with microscope tile. From Table 2, it can be concluded that larger braiding angle gave larger pore size. Based on another preliminary study conducted by Yahia (1997), it was reported that pore size to sustain bone into the scaffold growth was $150 \mu \mathrm{m}$ and the pore size to sustain soft tissue into the scaffold growth was $200 \mu \mathrm{m}-250 \mu \mathrm{m}$ [4]. Based on this, the sample with $40^{\circ}$ braiding angle was not an ideal scaffold for bone and soft tissue growth. The sample with $60^{\circ}$ can sustain bone growth, but it was not for the soft tissue. The sample with $80^{\circ}$ scaffold was an ideal scaffold.

Table 2. Braiding angle variation related to the pore size of scaffold

\begin{tabular}{cc} 
Braiding angle & Range of pore size $[\mu \mathrm{m}]$ \\
\hline $40^{\circ}$ & $105-126$ \\
$60^{\circ}$ & $127-170$ \\
$80^{\circ}$ & $199-321$ \\
\hline
\end{tabular}

From tensile test (Table 3), it could be concluded that larger braiding angle gave lower tensile strength. The tensile strength of human ACL is $38 \pm 9 \mathrm{MPa}$. It must be noticed that in this experiment the number of braids was just a single braid while human ACL is multilayered. For increasing the tensile strength, the number of braids can be added. Because the thickness of filament layer which was cut between two wires was not uniform, the roll filaments were classified into three classes. First was low weight class of between 0.0042 gram and 0.0193 gram. Second was medium weight class of $0.0194-0.0386$ gram. Third was high weight class between 0.0387 and 0.0537 gram. Then the filaments were grouped as their own classes. The purpose of this classification was to make uniform filaments in each scaffold because differences of filaments in a scaffold can be a trigger of fracture.

Table 3. The influence of braiding angle variation to the tensile strength of scaffold

\begin{tabular}{cccc}
\multirow{2}{*}{ Parameter } & \multicolumn{3}{c}{ Angle variation of braided-twisted fiber scaffold } \\
\cline { 2 - 4 } & $40^{\circ}$ & $60^{\circ}$ & $80^{\circ}$ \\
\hline Tensile strength & $1,318 \mathrm{MPa}$ & $0,22 \mathrm{MPa}$ & $0,024 \mathrm{MPa}$ \\
\hline
\end{tabular}


Table 4. Optical density value for cytotoxicity test with MTT-Assay

\begin{tabular}{cc}
\hline Parameter & Optical density (OD) value \\
\hline Media control & 0.0702 \\
Cell control & 0.2607 \\
Sample * & 0.2197 \\
\hline
\end{tabular}

A random sample was used for cytotoxicity test without repetition because the braiding angle variation is a physical variation; it should not influence the chemical condition of the scaffold. The result in Table 4 was substituted into the equation 2, and the result was $86.1 \%$. From previous study, it has been known that a material is toxic if the value of optical density was less than $60 \%$ [5]. From this result, it can be concluded the braided-twisted fiber scaffold was nontoxic materials. It was a nontoxic material because the toxic solvents such chloroform and toluene has been evaporated perfectly during the process of electrospinning. This phenomena was caused by the use of high voltage. Bigger braiding angle of braided twisted fiber scaffold has high degradation rate, bigger pore size, and lower mechanical strength. The braided-twisted fiber scaffold was a nontoxic material due to procentage of living cell of more than $60 \%$. The best braiding angle if reviewed from standard of pore size and cytotoxicity is $80^{\circ}$. The mechanical performance and the degradation rate can be repaired by adding braids in the scaffold. The best braiding angle with highlight in pore size related to capability of cell to be growth and its cytotoxicity level captured from the procentage of living cell is $80^{\circ}$. The optimalization of mechanical performance and the degradation rate might be repaired by adding the number of braided in the scaffold.

\section{Acknowledgement}

This paper is performed by the funding from Directorate of Higher Education (DIKTI). This investigation and the paper were supported in part, national nuclear agency for electrospinning unit, and also Mr.Ali Akbar and Mr. Jan Setiawan for the support and advice in this research.

\section{References}

[1] Ge, Z., Goh, C.H., Ramakhrisna, S., Lee, Eng. 2005. Characterization of knitted polymeric scaffolds for potential use in ligament tissue engineering. J. Biomater. Sci. Polymer Edn, Vol. 16, No. 9, pp. 1179-1192 (2005). Singapore.

[2] Freeman, Joseph W., Woods, Mia, Laurencin, Cato. 2006. Tissue engineering of the anterior cruciate ligament using a braid-twist scaffold design. Journal of Biomechanics 40 (2007) 20292036. USA.

[3] Gulotta, L., Rodeo, S. 2007. Biology of autograft and allograft healing in anterior cruciate ligament reconstruction. Hospital for Special Surgery, Weill Medical College of Cornell University, New York, USA.

[4] Yahia L (1997). Ligaments and ligamentoplasties. Berlin: Springer.

[5] Meizarini, A. 2005. Sitotoksisitas bahan restorasi cyanoacrylate pada variasi perbandingan powder dan liquid menggunakan MTT assay. Bagian Ilmu Material dan Teknologi Kedokteran Gigi Fakultas Kedokteran Gigi Universitas Airlangga. Indonesia

[6] Ramakhrisna, S., Kazutoshi, F., Teo, W., Lim, T.C., Ma, Zuwei. An introduction to electrospinning and fiber. Handbook. World Scientific Publishing Co. Singapore 
Materials, Industrial, and Manufacturing Engineering Research Advances 1.1

10.4028/www.scientific.net/AMR.845

The Influence of Braiding Angle Variation in Braided-Twisted Fiber Scaffold Based Poly L-Lactic Acid for Anterior Cruciate Ligament Reconstruction Application

10.4028/www.scientific.net/AMR.845.925

\section{DOI References}

[4] Yahia L (1997). Ligaments and ligamentoplasties. Berlin: Springer.

10.1007/978-3-642-60428-7 